\title{
Biogas plant on an industrial farm as an effective way of utilizing animal waste
}

\author{
Anna Smurzyńska ${ }^{1, *}$, Natalia Mioduszewska ${ }^{1}$, Michat Brzoski ${ }^{1}$, Dawid Chełkowski ${ }^{1}$, \\ Kamil Kozłowski ${ }^{1}$, and Karol Kupryaniuk ${ }^{2}$ \\ ${ }^{1}$ Poznan University of Life Sciences, Institute of Biosystems Engineering, Wojska Polskiego 50, \\ 60-637 Poznan, Poland \\ ${ }^{2}$ University of Life Sciences in Lublin, Department of Process Engineering, Doświadczalna 44 St., \\ 20-280 Lublin, Poland
}

\begin{abstract}
Industrial farms pose a serious threat to both people and the environment. The reason is that animal waste are produced in large quantities, which is a source of biogenic substances. Their irrational use, which is often common on industrial farms due to the limited area for fertilization, can lead to the eutrophication of water tanks and soils, and even to contamination with heavy metals and disease-causing microorganisms and pathogens. The economy of animal feces is accompanied by greenhouse emission and odors, the resulting emissions of volatile compounds also lead to the formation of acid rain. In view of the above, the possibilities of their management, which will be safe for ecosystems, are being sought for. While aeration, composting or fertilization of animal manure does not fully solve environmental protection or profitability issues, their anaerobic treatment allows not only for safe utilization, but also for energy production. Thus, the possibility of managing animal waste from a poultry, cattle and pig farms in biogas plants was presented. The presented calculations have slown that using them as a substrate in the fermentation process allows for effective utilization of animal manure being hazardous to the environment, in particular in the case of industrial farms.
\end{abstract}

\section{Introduction}

Industrial farms pose a serious threat to the local community, due to noise level, which accompanies the maintenance of a huge number of animals in a small area, but above all from troublesome odorous gas emissions [1-2]. It should be emphasized that on farms, animal waste is generated in huge amounts in the form of manure, manure or slurry, which are the source of organoleptically troublesome volatile compounds [3]. These emissions result from the decomposition of organic matter contained in animal faeces, which occurs in livestock buildings and during their development [4-6]. These physicochemical transformations are also a source of greenhouse gas emissions, including, above all, methane and nitrous oxide [7-9]. In addition, animal faeces are a rich source of microand macroelements, which is why they are commonly used as fertilizers. The presence

\footnotetext{
* Corresponding author: a.smurzynska@gmail.com
} 
of biogenic substances may also contribute to the contamination of soils and waters in the event of improper use becoming also a threat to the natural environment [10]. Another danger posed by the economy of animal feces is the presence of bacterial microflora (pathogenic microorganisms), which may lead to sanitary contamination if not proper hygiene is maintained [11]. Over the past years, the development of industrial farms has caused the occurrence of heavy metals in the animal faeces [12]. As research shows, the main source of contamination of animal manure is found in their feed [13-15]. It was the result of the often uncontrolled dietary supplementation of animals, the aim of which was not health protection, but to achieve rapid weight gain. The effects of utilizing animal manure contaminated with heavy metals as fertilizer are still visible even today in areas with developed production technology of livestock, where soil reclamation is highly needed [16-17].

Taking into consideration the above, there is a need to properly manage animal manure. One of the possibilities is the implementation of appropriate technologies for their processing. The most commonly used technology is aeration of slurry, composting of manure or fertilising the unprocessed animal [18-24]. These technologies are energy-consuming, causing high-emission that can lead to contamination of individual ecosystems, which is why other new solutions are being sought for that will ensure high efficiency while maintaining low operating costs. Subjecting animal manure to the methane fermentation process in biogas installations allows for their safe disposal into the form of digestated pulp, which is a highlyvalued fertilizer [25-27]. The process, which takes place in a sealed installation protects the environment against the greenhouse and odor emissions mentioned [28]. Subjecting animal faeces to the methane fermentation process also enables obtaining energy (thermal and/or electrical) [29-30]. In addition, studies show that natural fertilizers also perform a number of functions in the process of anaerobic decomposition, which is why they often are a valuable substrate enriching the fermentation mixture [31].

The aim of the following article is to conduct energy analyzes of biogas installations located on industrial farms that deal with poultry, cattle and pig production. The presented results indicate that animal waste in biogas production are beneficial. The presented data indicate not only the energy yield, but also the possibility of safe management of biogenic potential contained in the chicken droppings, manure and slurry throughout anaerobic treatment.

\section{Materials and methods}

The energy parameters for three biogas plants have been analyzed. The presented calculations were made for installations located on industrial farms dealing with animal production. The presented analyzes selected a poultry farm, a cattle farm and a pig farm. The number of kept animals in given facilities is shown in table 1 below.

Table 1. Animal population in industrial farms.

\begin{tabular}{|l|c|}
\hline \multicolumn{1}{|c|}{ Type of animals } & Number of animals [pcs.] \\
\hline \multicolumn{2}{|c|}{ farm I } \\
\hline laying hens & 52500 \\
\hline \multicolumn{2}{|c|}{ farm II } \\
\hline dairy cows & 1000 \\
\hline heifers and booklets & 930 \\
\hline calves & 425 \\
\hline \multicolumn{2}{|c|}{ farm III } \\
\hline porkers & 2000 \\
\hline sows & 300 \\
\hline
\end{tabular}


Farm II produces cattle in a closed cycle, which is an example of an industrial farm. For pig and poultry farm, the headage has been adopted, which requires an integrated permit in the event of industrial installation start-up [32]. The necessity to obtain a permit results from the fact that such a large number of bred animals is a serious threat to the environment. It is caused by, among others, the amount of manure produced, which is difficult to manage in such a small area like in case of industrial farms.

The calculation methodology presented by Szulc and Dach [33] was used in the calculations. A series of analyzes were carried out to estimate the energy efficiency of designed plant. The type and amount of available substrates in the form of chicken droppings generated by animals in individual farms were determined. Basing on the abovementioned the volume of biogas and methane produced was calculated, which allowed to determine the amount of energy produced and power efficiency of specific installations.

Studies of animal manure biogas and methane yield of individual industrial farms were carried out in the Ecotechnology Laboratory of the Institute of Biosystems Engineering at the University of Life Sciences in Poznan. The experiments were performed on the basis of internal procedures based on the adopted DIN 38 414-S8 and VDI 4630 standards. A detailed description of the methodology of the performed tests was presented in Cieślik et al. [34].

\section{Results and discussion}

\subsection{Amount of available substrates in industrial farms}

The biogas installations are designed to use animal faeces as substrates. In case of a poultry farm, it will be dung, in a cattle farm - manure, while in pig farm, slurry will be used. Table 2 summarizes the amount of natural fertilizers produced in given industrial farms.

Table 2. The amount of produced animal faeces in industrial farms [35-36].

\begin{tabular}{|c|c|c|c|}
\hline Type of animals & $\begin{array}{c}\text { Chicken } \\
\text { droppings } \\
\text { production } \\
{\left[\mathrm{Mg} \cdot \text { year }^{-1}\right]}\end{array}$ & $\begin{array}{c}\text { Manure } \\
\text { production } \\
{\left[\mathrm{Mg} \cdot \text { year }^{-1}\right]}\end{array}$ & 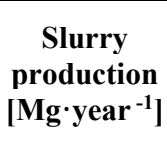 \\
\hline \multicolumn{4}{|c|}{ farm I } \\
\hline laying hens & 11.55 & - & - \\
\hline cumulative production & 11.55 & - & - \\
\hline \multicolumn{4}{|c|}{ farm II } \\
\hline dairy cows & - & 18000 & - \\
\hline heifers and booklets & - & 13020 & - \\
\hline calves & - & 1700 & - \\
\hline cumulative production & - & 32720 & - \\
\hline \multicolumn{4}{|c|}{ farm III } \\
\hline porkers & - & - & 5840 \\
\hline sows & - & - & 4106 \\
\hline cumulative production & - & - & 9946 \\
\hline
\end{tabular}

The cattle farm produces the largest amount of slurry per year, in an amount of 32.72 thous. $\mathrm{Mg}$. The pig farm produces about 10 thous. $\mathrm{Mg} \cdot \mathrm{year}^{-1}$, and the poultry farm over 11 $\mathrm{Mg} \cdot$ year $^{-1}$.

The results of biogas and methane production as well as the dry matter of substrates that can be utilized in given biogas installations in selected industrial farms are summarized in Table 3. 
Table 3. Biogas and methane yield of animal faeces.

\begin{tabular}{|c|c|c|c|}
\hline Animal feaces & $\begin{array}{c}\text { Dry matter } \\
{[\% \text { FM] }}\end{array}$ & $\begin{array}{c}\text { Cumulated biogas } \\
{\left[\mathrm{m}^{3} \cdot \mathrm{Mg} \text { FM] }\right.}\end{array}$ & $\begin{array}{c}\text { Methane percent } \\
{[\%]}\end{array}$ \\
\hline chicken droppings & 73 & 83 & 68 \\
\hline manure & 26 & 55 & 60 \\
\hline slurry & 14.7 & 35 & 65 \\
\hline
\end{tabular}

Research shows that the highest biogas yield can be obtained from chicken droppings $\left(83 \mathrm{~m}^{3} \cdot \mathrm{Mg} \mathrm{FM}^{-1}\right)$, while the least efficient substrate is slurry, which biogas yield is $35 \mathrm{~m}^{3} \cdot \mathrm{Mg}$ $\mathrm{FM}^{-1}$. Lower efficiency of biogas production coming from slurry results from a much lower dry matter content than other substrates tested. However, it should be highlighted that slurry fulfills a number of functions in the fermentation process, i.e. a diluting fermentation mixture, which contains the bacterial microflora responsible for the fermentation process and is a buffer for the optimal $\mathrm{pH}$ of the fermenting mixture, being a desirable substrate in biogas plants.

The methane production yield is at a similar level in the tested substrates. Lower methane production in the case of manure may result from a higher lignocellulosic substance content.

\subsection{Energy analysis}

While calculating energy and power amount of the installation, the biogas plant operation time was assumed: $t=8200 \mathrm{~h}$. The results of biogas and methane volume calculations for individual substrates in given industrial farms are presented in Table 4.

Table 4. The amount of biogas produced and energy calculations for biogas plants in individual industrial farms.

\begin{tabular}{|l|c|c|c|c|}
\hline \multicolumn{1}{|c|}{ Amount } & Unit & Farm I & Farm II & Farm III \\
\hline biogas volume & {$\left[\mathrm{m}^{3}\right]$} & 958.65 & 1799600.00 & 348118.75 \\
\hline methane volume & {$\left[\mathrm{m}^{3}\right]$} & 651.88 & 1079760.00 & 226277.19 \\
\hline power of the biogas plant & $\mathrm{kW}$ & 0.29 & 483.00 & 101.22 \\
\hline
\end{tabular}

According to the data contained in Table 4, the conducted analyzes indicated the lowest bioenergy production for chicken droppings, although the substrate showed the highest biogas yield, which results from the available amount of the substrate on the farm. In view of the above, the adopted headage of poultry stock allows for the micro-installations with the power of $0.3 \mathrm{~kW}$. It should be emphasized, however, that chicken droppings is characterized by a high nitrogen content released in the form of ammonia during fermentation. While ammonia is a nutrient source that allows for growth and functioning of microorganisms responsible for the fermentation process, its continuous growth inhibits the anaerobic decomposition and methane production [37-38]. Therefore, it is necessary to remove ammonium by precipitation of struvite, utilization of sorption deposits or constant control of $\mathrm{pH}$ and temperature in the fermentation chamber, which can be difficult to perform [39-42]. Other proposed solutions are the use of additional biomass available in the immediate proximity of the farm and formation of a fermented mixture of appropriate proportions, which will allow for proper decomposition in anaerobic conditions [43]. Therefore, the use of chicken droppings in the methane fermentation process will help protect the environment, especially against intense ammonia emissions, directly into the atmosphere - an odor gas.

In case of manure fermentation, the energy potential that can be obtained by the available amount of animal faeces on an industrial farm that allows for the production of $480 \mathrm{~kW}$ of power was determined. It should be emphasized, however, that due to dry matter content 
of manure at the level of $26 \%$, it is necessary to dilute the substrate, which will enable efficient liquid fermentation. Therefore, it would be necessary to use additional substrates with a lower content of this parameter, which are located in the immediate proximity of the farm, which will also maintain the cost-efficiency of the installation. In order to preserve the profitability of the designed biogas plant, it is worth using biodegradable substances being an industrial process by-product or other agro-food waste in an appropriate proportion [44-48].

Surry fermentation, on the other hand, uses a substrate with a relatively high dry matter content in relation to the slurry generated in individual farms. This is due to mechanized cleaning systems that consume a small amount of water and are widely used on industrial farms. The presented data show that the use of such a slurry allows for efficient monofermentation and the creation of a small biogas plant with the power of $100 \mathrm{~kW}$.

\section{Conclusion}

Animal waste is a serious threat to the natural environment, which is why safe ways of managing it being sought for. One of the available techniques is subjecting chicken droppings, manure and slurry to methane fermentation. The use of animal faeces as a substrate in biogas plants turns out to be the right solution, due to the generation of energy and digestate, which is a more valuable and safer fertilizer in contrast to raw animal manure. The analyzes carried out show the potential of animal faeces. It should also be emphasized that fermentation of chicken droppings and manure is possible when using them as cosubstrates in the fermentation mix.

\section{References}

1. L. Pan, S.X. Yang, J. DeBruyn, Biosyst. Eng. 96, Issue 3, 387-397 (2007)

2. J.-Q. Ni, C.A. Diehl, L. Chai, Y. Chen, A.J. Heber, T.-T. Lim, B.W. Bogan, Atmos Environ. 156, 113-124 (2017)

3. K V. Blanes-Vidal, M.N. Hansen, A.P.S. Adamsen, A. Feilberg, S.O. Petersen, B.B. Jensen, Atmos Environ. 43, 3006-3014 (2009)

4. Y. Kim, H.J. Ko, H.T. Kim, Y.S. Kim, Y.M. Roh, Ch.M. Lee, Ch.N. Kim, J Environ Manage. 88, Issue 2, 195-202 (2008)

5. L.K.K. Rodhe, J. Abubaker, J. Ascue, M. Pell, Å. Nordberg, Biosyst. Eng. 113, 4, 379394 (2012)

6. J. Sikora, M. Niemiec, A. Szeląg-Sikora, M. Kuboń, E. Olech, A. Marczuk, Przem Chem. 96(11), 2275-2278 (2017)

7. G. Koneswaran, D. Nierenberg, Environ. Health Perspect. 116 (5), 578-582 (2008)

8. J. Bellarby, R. Tirado, A. Leip, F. Weiss, J.P. Lesschen, P. Smith, Glob. Change Biol. 19, 3-18 (2013)

9. A. Smurzynska, J. Dach, R. Szulc, Acta Sci. Pol., Form. Circumiectus. 14, 3, 165-174 (2015)

10. Y. Hu, H. Cheng, S. Tao, Environment International 107, 111-130 (2017)

11. F.J. Bornay-Llinares, L. Navarro-i-Martínez, F. García-Orenes, H. Araez, M.D. PérezMurcia, R. Moral, Liv Sci. 102, 3, 237-242 (2006)

12. Wang, Y. Dong, Y. Yang, G.S. Toor, X. Zhang, J Environ Sci. 25, 12, 2435-2442 (2013)

13. Y. Li, D.F. McCrory, J.M. Powell, H. Saam, S.D.J. Jackson, Dairy Sci. 88, 2911-2922 (2005)

14. Y.-X. Li, W. Li, J. Wu, L.-C. Xu, Q.-H. Su, X.J. Xiong, Environ. Sci. (China) 19, 610615 (2007) 
15. R.A.R. Huaynate, M.C. Thomaz, R.N. Kronka, A.L. Fraga, A.J. Scandolera, F.E.L. Budiño, Brazil. Arch. Biol. Technol. 49, 385-392 (2016)

16. Q. Wang, Y. Cui, X. Liu, Y. Dong, P. Christie, Journ. Environ. Sci. Health 38, 823-838 (2003)

17. J. Dach, D. Starmans, Agriculture, Ecosyst Environ. 107, 309-316 (2005)

18. M. Molodovskaya, O. Singurindy, B.K. Richards, T.S. Steenhuis, Bioresour. Technol. 99, 18, 8643-8648 (2008)

19. D. Wojcieszak, J. Przybył, A. Lewicki, A. Ludwiczak, A. Przybylak, P. Boniecki, K. Koszela, M. Zaborowicz, K. Przybył, K. Witaszek. Proc. SPIE 9631, Seventh International Conference on Digital Image Processing (ICDIP 2015), 963118 (2015)

20. R. Caceres , N. Coromina , K. Malinska , O. Marfa, Bioresour. Technol. 179, 398-406 (2015)

21. R. Caceres, N. Coromina, K. Malinska, F.X. Martinez-Farre, M. Lopez, M. Sava, O. Marfa 2016. Waste Manage. 58, 118-125 (2016)

22. M. Zaborowicz, D. Wojcieszak, K. Górna, S. Kujawa, R. J. Kozłowski, K. Przybył, N. Mioduszewska, P. Idziaszek, P. Boniecki. Proc. SPIE 10033, Eighth International Conference on Digital Image Processing (ICDIP 2016), 100332G (2016)

23. Y. Chu, Ch. Fang, H. Wang, X. Wu, Y. Gu, J. Shu, Chin. J. Chem. Eng. 25, 10, 1505$1511(2017)$

24. M. Neugebauer, P. Sołowiej, J Clean Prod. 156, 865-875 (2017)

25. W. Czekała, S. Bartnikowska, A. Lewicka, A. Bugała, Z. Zbytek, A. Lewicki, MATEC Web of Conferences 60, 04005 ICCBS (2016)

26. P. Abdeshahianan, J.S. Lim, W.S. Ho, H. Hashim, Ch.T. Lee, Renew Sust Energ Rev 60, 714-723 (2016)

27. W. Czekała, J. Dach, R. Dong, D. Janczak, K. Malińska, K. Jóźwiakowski, A. Smurzyńska, M. Cieślik, Biosyst. Eng. 160, 25-29 (2017)

28. W. Czekała, J. Ecol. Eng. 18(5), 180-185 (2017)

29. H. Afazeli, A. Jafari, S. Rafiee, M. Nosrati, Renew Sust Energ Rev 34, 380-386 (2014)

30. W. Czekała, J. Dach, J., J. Przybył, P. Boniecki, A. Lewicki, P. C. Rodriguez Carmona, D. Janczak, H. Waliszewska Proceedings of the 2nd International Conference on Energy \& Environment: Bringing Together Engineering and Economics, 520-525 (2015)

31. A. Smurzyńska, W. Czekała, K. Kupryaniuk, M. Cieślik, A. Kwiatkowska, Probl. Inż. Rol. R. 24, 4(94), 117-127 (2016)

32. Regulation of the Minister of Environment 27.08.2014

33. R. Szulc, J. Dach, Kierunki rozwoju ekoenergetyki $w$ polskim rolnictwie (Polskie Towarzystwo Inżynierii Rolniczej w Krakowie, 2014)

34. M. Cieślik, J. Dach, A. Lewicki, A. Smurzyńska, D. Janczak, J. Pawlicka-Kaczorowska, P. Boniecki, P. Cyplik, W. Czekała, K. Jóźwiakowski, Energy 115, 1495-1502 (2016)

35. W. Romaniuk, Magazynowanie nawozu naturalnego (Warszawa, Instytut Budownictwa, Mechanizacji i Elektryfikacji Rolnictwa, 2005)

36. Regulation of the Council of Ministers from 18.05.2005, annex no. 1

37. Y. Chen, J.J. Cheng, K.S. Creamer, Bioresour. Technol. 99, 4044-4064 (2008)

38. F. Abouelenien, W. Fujiwara, Y. Namba, M. Kosseva, Bioresour. Technol. 10, 6368$6373(2010)$

39. S. Uludag-Demirer, G.N. Demirer, S. Chen, Process Biochem. 40, 3667-3674 (2005)

40. H. Q. Wang, Y. Yang, C. Yu, H. Huang, M. Kim, C. Feng, Z. Zhang, Bioresour. Technol. 102, 7064-7068 (2011)

41. L. Ho, G. Ho, Water Res. 46, 4339-4350 (2012)

42. D.E. Belostotskiy, E.E. Ziganshina, M. Siniagina, E.A. Boulygina, V.A. Miluykov, A.M. Ziganshin, Bioresour. Technol. 193, 42-52 (2015)

43. X. Wang, G. Yang, Y. Feng, G. Ren, X. Han, Bioresour. Technol. 120, 78-83 (2012) 
44. W.N. Chan, Z. Fu, M.T. Holtzapple, Biomass Bioenerg. 35, 10, 4134-4144 (2011)

45. J. Li, L.Y. Wei, Q.W. Duan, G.Q. Hu, G.Z. Zhang, Bioresour. Technol. 156(2), 307-313 (2014)

46. T. Dias, R. Fragoso, E. Duarte, Bioresour. Technol. 164, 420-423 (2014)

47. W. Czekała, A. Smurzyńska, M. Cieślik, P. Boniecki, K. Kozłowski Energy and Clean Technologies Conference Proceedings, International Multidisciplinary Scientific GeoConference-SGEM III, 227-233 (2016)

48. K. Kozłowski, A. Lewicki, P. Solowiej, M. Neugebauer, A. Smurzynska Energy and Clean Technologies Conference Proceedings, International Multidisciplinary Scientific GeoConference-SGEM III, 345-350 (2016) 